\title{
Self referral to accident and emergency department: patients' perceptions
}

\author{
Surinder Singh
}

\begin{abstract}
A study was conducted (a) to assess the number of patients registered with a south London general practice who over 11 weeks referred themselves to an accident and emergency department, $(b)$ to identify the characteristics of those patients, and $(c)$ to determine their perceptions of the services and resources available within their general practices and of the role of accident and emergency departments. Two hundred and thirty four patients referred themselves to a casualty department during the study period, of whom $217(93 \%)$ were interviewed by means of a semistructured questionnaire.

Of the 217 patients interviewed, only 15 had tried to contact their general practitioner before attending the casualty department. Eighty nine patients considered that their problem was urgent and required immediate attention and many that they would need an $x$ ray examination. A substantial minority of patients thought that their doctor would not be available.

It is concluded that patients' perceptions of their problems and of access to their doctors are the main determinants of self referral to a casualty department. These findings have important implications for patient education.
\end{abstract}

\section{Introduction}

A substantial proportion of patients attending accident and emergency departments have conditions that could adequately be managed by their general practitioner. ${ }^{12}$ In the South East Thames region between 1968 and 1981 the number of new attendances per 100000 resident population rose by $36 \%$ and cost an estimated $£ 18 \mathrm{~m}$ a year. ${ }^{3}$ Why are increasing numbers of patients still going to the casualty department? Most studies have examined patients' stated reasons for attendance. ${ }^{124}$ Only one has tried to identify their perceptions of their condition and of the role of their general practitioner. ${ }^{5}$ I hypothesised that the most important factor was the patients' perceptions of their illness and of the service provided by their general practitioner.

This paper reports the results of a research project aimed at $(a)$ assessing the number of patients registered with a south London practice who over 11 weeks attended a casualty department, $(b)$ identifying the characteristics of those who referred themselves, and (c) defining patients' perceptions of services and resources within their general practice and of the role of accident and emergency departments. Centre, London SE26 4TG Surinder Singh, MRCGP, general practitioner trainee

Correspondence to: 53 Shell Road, Lewisham, London SE13 7DF

\section{Patients and methods}

The patients studied were registered with a practice having a list size of 12000 . The surgery was open continuously from $830 \mathrm{am}$ to $7 \mathrm{pm}$ Mondays to Fridays and from 830 am to 12 noon on Saturdays. The doctors did their own night calls. An appointments system was in operation, but even when a surgery was fully booked patients with "emergencies" (as defined by themselves) were seen during that surgery session.

The practice population was served by three accident and emergency departments in the district. The study was undertaken over 11 weeks in the summer of 1986 . The sample population consisted of all self referred patients who attended any of the three casualty departments during the study period. The general practitioner was notified of all attendances by a brief discharge summary, and no patients were referred back to their general practitioner without prior assessment. Patients were interviewed by means of a semistructured questionnaire.

\section{Results}

Of the 234 patients who referred themselves to accident and emergency departments during the study period, $217(93 \%)$ were interviewed.

Age and sex-A total of 102 of all patients in the series were under 16 and 78 were aged 16-30. Of the younger group, 46 were under $5 \mathrm{~s}$ brought to the casualty department by a parent and 56 were aged 5-16. Twelve patients were over 60 . The sexes were equally represented in all age groups.

Time of day-One hundred and fifty seven patients attended the casualty department during the hours that the health centre was open - that is, between $830 \mathrm{am}$ and $7 \mathrm{pm}$ and on Saturday mornings (table). Twenty five patients attended after midnight. The single largest number of patients who attended an accident and emergency department did so in the three hours before the health centre closed, corresponding almost exactly to the doctors' surgery times.

Perceptions-Eighty nine patients cited urgency as a factor in their decision to bypass the general practitioner and go direct to the casualty department. Fifty three patients thought that they would need an $x$ ray examination and gave this as the reason for self referral. Thirty nine patients thought that their doctor was not available after surgery hours and 16 that it would be quicker going to the casualty department. Other responses included advice from friends and relatives ( 15 patients) and being out of the practice area at the time of the emergency (14). Twelve patients specifically cited not wanting to bother their doctor as their reason for attendance.

\section{Comment and conclusions}

This study was undertaken over 11 weeks in the summer, when workload tended to be lighter. Extrapolated over 12 months the attendances represented the equivalent of 70 surgeries being held in an accident and emergency department. 
Times of day of self referral to accident and emergency department by all 234 patients

\begin{tabular}{|c|c|c|c|c|c|c|c|c|c|}
\hline $\begin{array}{l}\text { Time of day: } \\
\text { No of patients: }\end{array}$ & $\begin{array}{c}0830- \\
23\end{array}$ & $\begin{array}{c}1100- \\
34\end{array}$ & $\begin{array}{c}1330- \\
44\end{array}$ & $\begin{array}{c}1600- \\
56\end{array}$ & $\begin{array}{c}1900- \\
28\end{array}$ & $\begin{array}{c}2130- \\
17\end{array}$ & $\begin{array}{c}2400- \\
20\end{array}$ & $\begin{array}{c}0230- \\
7\end{array}$ & $\begin{array}{c}0500-0829 \\
5\end{array}$ \\
\hline
\end{tabular}

Of the patients who were interviewed, only 15 (6\% of the whole series) had tried to contact their doctor before attending the casualty department. This supports the hypothesis that the factors influencing patients' decisions to seek emergency treatment relate to perceptions both of their problem and of the primary care services available to deal with it. Patient education could reduce inappropriate hospital attendance, but this is difficult to provide in a busy casualty department. Practice information leaflets ${ }^{6-8}$ could be used to ask patients to contact their general practitioner before going to a casualty department. Alternatively, the doctor could discuss the reasons for going to hospital when the patient attends for follow up in the surgery. Hopefully this would alter the future health seeking behaviour. ${ }^{9}$ Finally, the nurse practitioner may be in the best position to provide an emergency service and advise on the management of minor injuries and self limiting disorders. ${ }^{67}$

This study has shown that in a practice providing 24 hour accessibility patients' perceptions of their problem and of the availability of their general practitioner are the main reasons for attending a casualty department. This problem can be dealt with satisfactorily only by educating patients in the most appropriate use of available resources. This responsibility must be shared between the two services concerned.

I thank all patients who participated in this study and the staff at the Jackson practice, Sydenham Green Health Centre. I am indebted to Dr B Essex for advice and support during the study.

1 Myers P. Management of minor medical problems and trauma: general practice or hospital? f R Soc Med 1982;75:879-83.

2 Davison AG, Hildsey ACC, Floyes MA. Use and misuse of an accident and 1983;76:37-40.

3 South East Thames Regional Health Authority. Accident and emergency services: a strategy document of the South East Thames Regional Health Authority. a strategy documuary 1983.

4 Wilkinson A, Kazantzis G, Williams DJ, Dewar RAD, Bristow KM, Miller DL. Attendance at a London casualty department. $\mathcal{f} R$ Coll Gen Pract 1977;27:727-33.

5 Davies T. Accident department or general practice? Br Med f 1986;292:241-3.

6 Cumberledge J. Neighbourhood nursing - a focus for care. Report of the community nursing review. London: $\mathrm{HMSO}, 1986$.

Secretaries of State for Social Services, Wales, Northern Ireland, Scotland. Primary health care. An agenda for discussion. London: HMSO, 1986. (Cmnd 9771.)

8 Royal College of General Practitioners. The fromt line of the health service. London: RCGP, 1987. (Report from General Practice, No 25.)

9 Stot $\mathrm{NCH}$, Davis RH. The exceptional potential in each primary care consultation. F R Coll Gen Pract 1979;29:201-5.

(Accepted 31 August 1988)

\section{BOOKS RECEIVED}

Accident and emergency

Contemporary Issues in Emergency Medicine. "Problems in Pediatric Emergency Medicine." Ed R C Luten. Series editor A Harwood-Nuss. ( $\mathrm{Pp}$ 312; figs; £26.50.) New York: Churchill Livingstone, 1988. ISBN 0-443. 08579-X

\section{Acquired immune deficiency}

syndrome

AIDS: a Guide for the Primary Physician. Ed K K Holmes, A G Motulsky. (Pp 66; figs; \$15 paperback.) Seattle: (Pp 66; figs; \$15 paperback.) Seattle: University of Washing

AIDS and AIDS Risk Patient Care. Ed H Jäger. ( $\mathrm{Pp} 224 ;$ ₹29.95.) Chichester: Ellis Horwood, 1988. Distributed by John Wiley and Sons. ISBN 0-74580506-X

Skin Signs in AIDS: Textbook of AIDS/HIV Infection-Related DermatoAIDS/HIV Infection-Related Dermato-
logy. K Weismann, C S Petersen, J logy. K Weismann, C S Petersen, J
Sondergaard, G L Wantzin. (Pp 176; colour plates; DKK 230.) Copenhagen: Munksgaard, 1988. ISBN 87 16-06914-5

\section{Alternative medicine}

Medical Acupuncture: Acupuncture and the Inner Healer. I Schneideman. ( $P$ 352 ; figs; $£ 60$, post and packing $£ 3.50$ UK, $£ 5$ overseas.) Available from Eas Asia Company, 103 Camden High Street, London NW1 7JN. ISBN 0-7316-0277-3.

\section{Anaesthesi}

Positioning the Surgical Patient. J M Anderton, $R$ I Keen, $R$ Neave. ( $P p$ 128; figs; £12.95 paperback.) London: Butterworth, 1988. ISBN $0-407$ 01220-6.

\section{Cardiology}

Progress in Cardiology. Vol 16. Ed P N Yu, J F Goodwin. (Pp 184; figs; £19.) Philadelphia: Lea and Febiger, 1988 ISBN 0-8121-1144-3.

\section{Cardiovascular system}

Developments in Cardiovascular Medicine. "The Right Ventricle." Ed M A Konstam, J M Isner. (Pp 352; figs;
£76.25.) Boston: Kluwer, 1988. ISBN 0-89838-987-9.

Dermatology

$A B C$ of Dermatology. Articles published in the British Medical foumol. P K Buxton. (Pp 98; colour plates; $£ 10.95$, overseas $£ 13$ ( $\$ 22$ ) paperback, including postage, airmail overseas. BMA members $\$ 9.95$, overseas $\$ 12$ (\$20), including postage.) London: British Medical Association, 1988 ISBN 0-7279-0220-2.

Pediatric Dermatology. Ed L A Schachner, R C Hansen. (Pp 1860; fig and colour plates; $\{225$, in 2 volumes.) New York: Churchill Livingstone, 1988. ISBN 0-443-08432-7.

Diabetes

Management and Education of the Diabetic Patient. R Metz, J W Benson, Jr. (Pp 256; figs; 113.95 paperback.) Philadelphia: Saunders, 1988. Distributed by Harcourt Brace Jovanovich. ISBN 0-7216-1945-2.

\section{Ear, nose, and throat}

Dilemmas in Otorhinolaryngology. Ed D F N Harrison. (Pp 388; £45.) Edinburgh: Churchill Livingstone, 1988. ISBN 0-443-03554-7.

Lasers in Medicine and Surgery Series. "Lasers in Otolaryngology." Ed J A Carruth, G T Simpson. General editors J A S Carruth, S N Joffe. (Pp 196; figs; $£ 25$.) London: Chapman and Hall, 1988. ISBN 0-412-30940-8.

Recent Advances in Otolaryngology. No 6. Ed R F Gray, J A Rutka. (Pp 264; figs; £35.) Edinburgh: Churchill Livingstone, 1988. ISBN 0-443-03765-5.

\section{Endocrinology}

Case Presentations in Endocrinology and Diabetes. P H Baylis, G V Gill, P Kendall-Taylor. (Pp 176; $£ 9.95$ paperback.) London: Butterworth, 1988 ISBN 0-407-00543-9.

Geriatrics

Medicine in Old Age. "Psychological Assessment of the Elderly." Ed J P Assessment of the Elderly." Ed J P W29.50.) Edinburgh: Churchill Livingstone, 1988. ISBN 0-443-03320-X
ing
Yearbook of Geriatrics and Gerontology 1988. Ed J C Beck, I B Abrass, J R Burton, et al. (Pp 320; figs; £31.50.) Chicago: Year Book Medical Publishers, 1988. Distributed by Wolfe Medical, 1988. ISBN 0-8151-0631-9.

\section{Haematology}

Pure Red Cell Aplasia. E N Dessypris. (Pp 176; figs; £21.) Baltimore: The Johns Hopkins University Press, 1988. ISBN 0-8018-3572-0.

\section{Health care issues}

American Health Care: Realities, Rights, and Reforms. C J Dougherty. (Pp 240; £22.50.) New York: Oxford University Press, 1988. ISBN 0-19505271-4.

Bath Social Policy Papers. No 13. "Charging in the Private Nursing Home Industry." H Bartlett, $M$ Snell. (Pp 36: $\{3.50$ paperback, including (Pp 36: ₹3.50 paperback, including postage and packing.) 1988. Available from the Centre for the Analysis
of Social Policy, School of Social of Social Policy, School of Social
Sciences, University of Bath, Bath Sciences, University of Bath,
BA2 7AY. ISBN 0-86197-079-9.

New Model Management: Griffiths and the NHS. A Report. P Strong, J Robinson. (Pp 180; £20 paperback, including postage and packing.) 1988. Available from the Nursing Policy Available from the Nursing Policy wick, Coventry CV4 7AL.

\section{Intensive care}

Clinical Decision Making. "Decision Making in Surgical Critical Care." R H Demling, R F Wilson. (Pp 264 $£ 36.50$.) Toronto: Decker, 1988. Distributed by Blackwell Scientific, 1988. ISBN 1-55664-001-3.

Progress in Critical Care Medicine. Vol 3. "Critical Care Cardiology." Ed 3. "Critical Care Cardiology." Ed Massion. (Pp 268; figs and colour Massion. (Pp 268; figs and colour
plates; £59.10.) Basel: Karger, 1988. plates; $£ 59.10$.) Basel: Karger, 1988.
Distributed by John Wiley and Sons. Distributed by John W
ISBN 3-8055-4734-X.

\section{Prostaglandins}

Prostaglandins: Biology and Chemistry of Prostaglandins and Related Eicosanoids. Ed P B Curtis-Prior. (Pp 724 figs; £120.) Edinburgh: Churchill
Livingstone, 1988. ISBN 0-44302519-3.

\section{Psychology}

Adult Abnormal Psychology. Ed Miller, P J Cooper. (Pp 392; £29.95.) Edinburgh: Churchill Livingstone, 1988. ISBN 0-443-03513-X

Male Homosexuality: a Contemporary Psychoanalytic Perspective. R C Friedman. (Pp 312; £27.50.) New Haven, Connecticut: Yale University Press, 1988. ISBN 0-300-03963-8.

\section{Radiology}

Diagnostic Imaging of the Nose and Paranasal Sinuses. G A S Lloyd. (P 192; figs; £66.) London: Springer, 1988. ISBN 3-540-19518-1.

\section{Rehabilitation}

Contemporary Challenges to the Rehabilitation Counseling Profession. Ed S E Rubin, N M Rubin. (Pp 368; £23.75.) Baltimore: Brookes, 1988. ISBN 0-933716-85-0.

\section{Respiratory medicine}

Mainstream Medicine: Respiratory Medicine. J A R Friend, J S Legge. (Pp 320; 112.95 paperback.) London: Heinemann Medical, 1988. ISBN 0433-10909-2.

Monographs in Clinical Cytology. Vo 11. "Cytopathology of Pulmonary Disease." D L Rosenthal. Series edito G L Wied. (Pp 248; figs; $\mathbf{6 0 . 9 0}$.) Basel: Karger, 1988. Distributed by John Wiley and Sons. ISBN 3-8055 4740-4.

\section{Sports medicine}

Soft. Tissue Injuries in Sport. S Lachmann. (Pp 144; figs; 116.95 tific, 1988. ISBN 0-632-01964-6.

Ultrasonics

Genitourinary Ultrasound: a Text/Atlas. Ed B G Coleman. (Pp 560; figs; £52. New York: Igaku-Shoin, 1988. Distributed by Williams and Wilkins. ISBN 0-89640-130-8.

Obstetrical Measurements in Ultrasound: a Reference Manual. A B Kurtz, B B

Goldberg. (Pp 232; figs; £34.) Chicago: Year Book Medical PubMedical. ISBN 0-8151-5222-1.

\section{Miscellaneous}

The Medicine Chest: Your Family's Guide to Prescription Drugs. G Martlew, $S$ Silver. (Pp 400; $£ 4.99$ paperback.) Wellingborough: Thorsons, 1988. ISBN 0-7225-1568-5

Positive Self-Talk: What to Say When Talking to Youself. A G Dawrant. (Pp 32; 14 paperback.) Stress Manage- 